\title{
STUDY OF ECTOPIC BONE FORMATION IN EXPERIMENTAL SPINAL CORD INJURED RABBITS
}

\author{
By KiYoji IzUmi, M.D. \\ Department of Orthopedic Surgery, Kumamoto University Medical School, Honjo \\ I-I-I, Kumamoto, fapan.
}

Summary. There was no significant difference of incidence of ectopic bone formation between paraplegic rabbits and non-paraplegic rabbits under the same immobilization and passive movement of the posterior legs. This result suggests that ectopic bone may be produced by forcible passive movement of paralytic legs, as legs of paraplegic patients are in an immobilized condition because of the paralysis.

Enchondral ossification was significantly observed histologically more frequently in paraplegic rabbits than in non-paraplegic rabbits. We suspect that the reason may be because the paralytic legs are poorly oxygenated because of blood stasis.

Key words: Experimental spinal cord injury; Ectopic bone formation; Passive movements.

\section{Introduction}

THERE are many descriptions of ectopic bone formation occurring in patients who have sustained injuries of the spinal cord, (Déjérine et al., I9ı; Silver, I969; Couvée, I97I; Scher, I976; Hernandez et al., I978). The pathogenesis is still unknown, although many opinions have been presented. It is emphasized that early gentle rehabilitation is very important to prevent ectopic bone formation in paraplegics and tetraplegics (Damanski, I96I).

There are few reports of experimentally produced ectopic bone in the paraplegic state, and of the examination of the influence of paraplegia upon ectopic bone formation (Takada, I977). Nor have there been experiments in which the influence of passive movement of paraplegic legs on ectopic bone formation has been examined.

Experiment $I$.

The influence of paraplegia on ectopic bone formation induced by decalcified bone matrix (DBM) was examined using the method of Urist (Urist, I965).

\section{Materials and Method}

Fifty-six rabbits (female, New Zealand Whites) weighing $2 \cdot 5-3 \mathrm{~kg}$ were used in this study. The animals were anaesthetised with intravenous sodium pentobarbiturate $(30 \mathrm{mg} / \mathrm{kg})$. The diaphysis of the femur of the 5 rabbits was resected in sterile conditions and the soft tissues were removed. After the denuded bones were decalcified in $0.6 \mathrm{~N} \mathrm{HCL}$ solution for 4 days using Urist's method, they were washed in water and discs of $5 \mathrm{~mm} /$ diameter were punched out and lyophilised. These discs are the decalcified bone matrix (DBM). Four discs of DBM were implanted routinely in the 
quadriceps muscle of the right thigh of 5 I of the 56 rabbits. Twenty-seven of the $5 \mathrm{I}$ rabbits underwent laminectomy at the thoraco-lumbar junction, and the spinal cords were injured just before implantation of DBM (Group A). The other 24 (of the 5 I rabbits) did not have a laminectomy (Group B). The discs of DBM inserted into the quadriceps muscle were removed 3 weeks after implantation and compared both in soft X-ray pictures and histologically. All specimens were radiographed by soft X-ray in the same condition ( $50 \mathrm{~cm}$ distant, $40 \mathrm{KVp}$, I I mA, $8 \mathrm{sec}$ ). Some of the 5 I rabbits were sacrificed I or 2 weeks after implantation of the discs. Some of the 5 I rabbits were excluded, because they were infected. Finally, i 8 rabbits in Group A and 13 rabbits in Group B were studied.

\section{Results}

In soft X-ray pictures ectopic bone formation was found in $\mathrm{I} 4$ of $\mathrm{I} 8$ rabbits ( 77 per cent) in Group A and in nine of 13 rabbits (69 per cent) in Group B. There was no significant difference in the incidence of ectopic bone formation between the two groups (Table I). Ectopic bone in Groups A and $\mathrm{B}$ was found disc-like shaped in soft X-ray pictures. There was little difference between the two groups (Fig. I).

\section{TABLE I}

Soft X-ray pictures

\begin{tabular}{lcc}
\hline & No. of rabbits & Ossification \\
\hline A & I 8 & I4 \\
B & I3 & 9 \\
Total & 3 I & 23 \\
\hline
\end{tabular}

n.s. (Statistically not significant)

In the histological examination of the ectopic bone, chondrocytes were found more frequently in Group A than in Group B at 3 weeks $(P<0.00 I$ Fisher's exact test) (Table II, Figs 2, 3). It may be thought that enchondral ossification was apt to occur in Group A, at 3 weeks. On the other hand woven bone margined by osteoblasts was observed in Group B, at 3 weeks (Fig. 3). The rabbits sacrificed I or 2 weeks after implanting the discs showed no ossification either radiologically nor histologically.

\section{Experiment $I I$.}

Ectopic bone was produced in paraplegic rabbits and in non-paraplegic rabbits according to Michelsson's method (Michelsson et al., I980). The influence of both paraplegia and of passive movement of posterior legs, or of either upon ectopic bone formation was examined both radiologically and histologically.

\section{Materials and Methods}

Forty-one rabbits (female, New Zealand Whites), weighing 2.5 to $3.0 \mathrm{~kg}$ were used. The animals were anaesthetized with intravenous pentobarbiturate $(30 \mathrm{mg} / \mathrm{kg})$. 
A

B

FIG. I

Soft X-ray pictures, disc-like shaped ossifications are shown in both Group A and B.

TABLE II

Histological findings

\begin{tabular}{lcc}
\hline & No. of rabbits & Cartilage cell \\
\hline A & I 8 & I 5 \\
B & I 3 & 2 \\
Total & 3 & I 7 \\
\hline$P<0.00 I^{\star \star \star}$ (Fisher) &
\end{tabular}

Ten of 4I rabbits underwent laminectomy at the thoraco-lumbar junction and their spinal cords were injured. Just after injury, the right posterior leg was immobilized with a plaster splint with the knee in extension. From the next day the splint was removed once a day and then forcible passive movement of both posterior legs of the Io rabbits was performed 300 times a day for 3 weeks by hand (Group J).

Nine of $4 \mathrm{I}$ rabbits had the same treatment as Group J except that their spinal cords were not damaged (Group K).

Nine of 4I rabbits had the same treatment as Group J except that they 

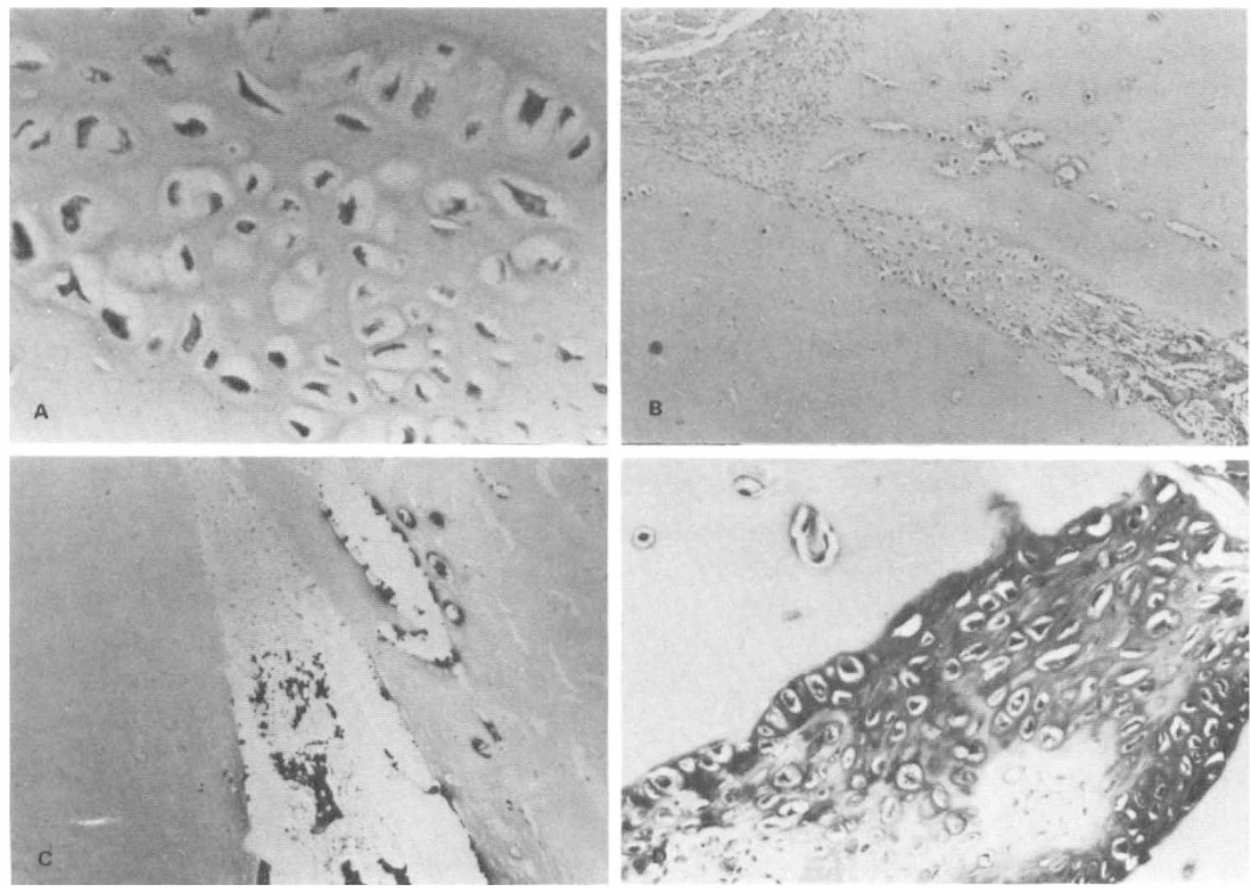

FIG. 2

Histological findings in Group A, A; hematoxylin eosin staining (H.E.) ( $\times 600$ ), B; H.E. ( $\times 60), C ;(\times 60)$, D; Safranin-o-first green staining (S.O.F.) $(\times$ I 50). Von-Kossa staining

(V.K.)

had gentle passive movements to maintain the normal range of motion in both legs (Group L).

Six of 4 I rabbits had the same treatment as Group K except for gentle passive movements (Group $\mathrm{M}$ ).

The right posterior leg of the other seven rabbits was only immobilized by a plaster splint with the knee in extension, for 3 weeks (Group N).

After each treatment was repeated in the five groups all the rabbits were sacrificed, and both posterior legs of all rabbits were disarticulated at the hip joints and compared with one another, radiologically and histologically. The whole of both posterior legs were radiographed in the same condition by soft X-ray ( $50 \mathrm{~cm}$ distant, $40 \mathrm{KVp}$, I I $\mathrm{mA}, 20 \mathrm{sec}$; lateral view or $40 \mathrm{sec}$; anterio-posterior view).

The blood gas of the right posterior leg was measured in eight rabbits of Group J and six rabbits of Group $\mathrm{K}$ respectively by Corning $\mathrm{pH} / \mathrm{Blood}$ Gas Model I 65 just before the animal was sacrificed at 3 weeks.

\section{Results}

In soft X-ray pictures ectopic bone occurred more frequently in Groups J and $\mathrm{K}$, rather than in Groups $\mathrm{L}, \mathrm{M}$ and $\mathrm{N}$ at the right side $(\mathrm{P}<0.05$, Fisher's exact test). But there was no significant difference in the incidence of ectopic bone formation between Groups J and K. Ectopic bone 


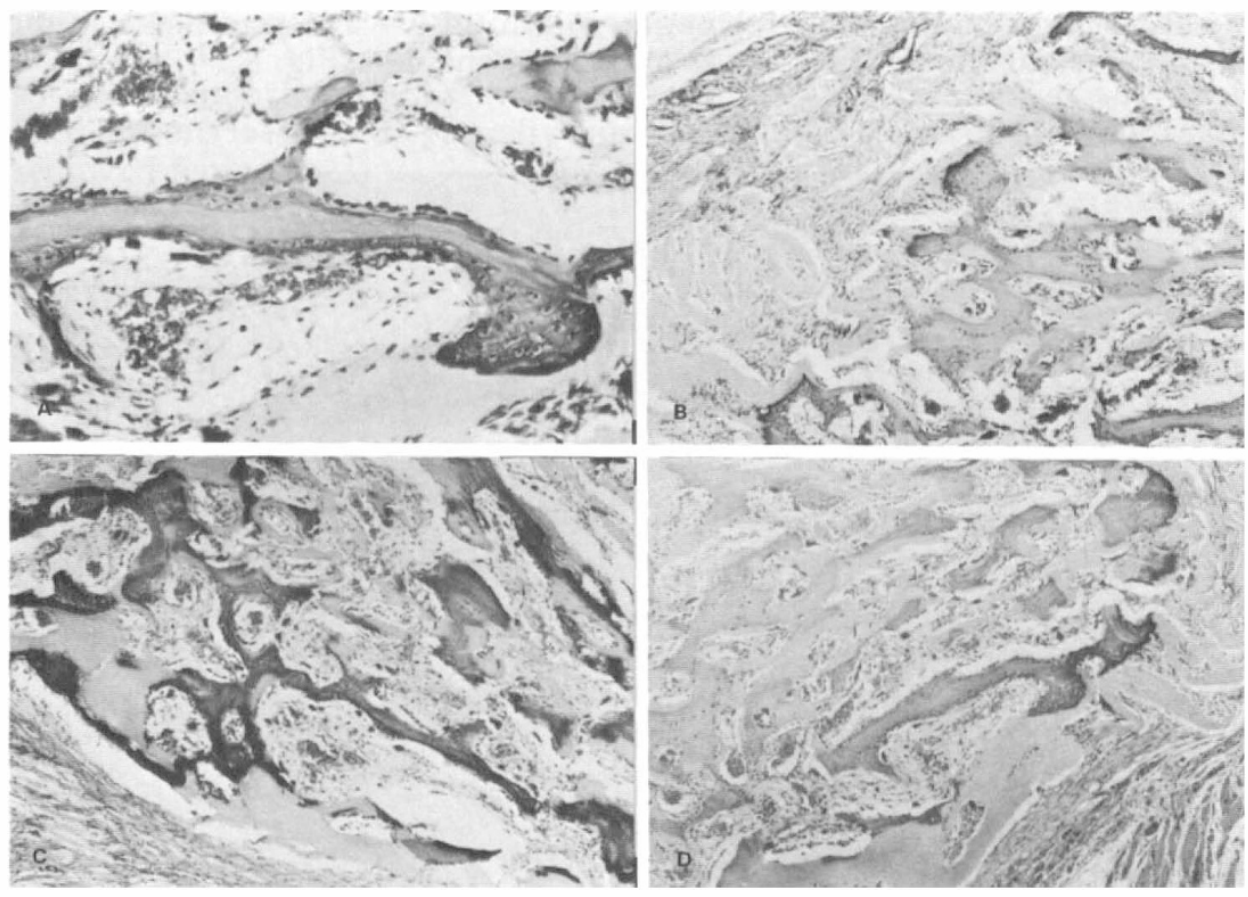

FIG. 3

Histological findings in Group B, A; H.E. $(\times 300)$, B; S.O.F. $(\times 60)$, C; V.K. $(\times 60)$, D; H.E. $(\times 60)$.

was found more frequently in the immobilized (right) legs than at the nonimmobilized (left) legs in both Groups $\mathrm{J}$ and $\mathrm{K}(\mathrm{P}<0.05$, binomial distribution test). There was no significant difference in ectopic bone formation between both sides in Groups L, M and N (Table III). In soft $\mathrm{X}$-ray pictures ectopic bone formation in Group J which was zonal in the antero-medial site of the thighs was similar to the one in Group K. On

\section{TABLE III}

Soft X-ray pictures

binomial distribution test

\begin{tabular}{|c|c|c|c|}
\hline & & No. of rabbits & Ossification \\
\hline $\mathrm{J}$ & $\begin{array}{l}\text { right } \\
\text { left }\end{array}$ & $\begin{array}{l}\text { IO } \\
\text { IO }\end{array}$ & ${ }_{2}^{9}\left(P<0.05^{\star}\right)$ \\
\hline $\mathrm{K}$ & $\begin{array}{l}\text { right } \\
\text { left }\end{array}$ & $\begin{array}{l}9 \\
9\end{array}$ & ${ }_{0}^{9}\left(P<0.0 I^{\star \star}\right)$ \\
\hline $\mathrm{L}$ & $\begin{array}{l}\text { right } \\
\text { left }\end{array}$ & 9 & $\begin{array}{l}\mathrm{O} \\
2\end{array}$ (n.s.) \\
\hline M & $\begin{array}{l}\text { right } \\
\text { left }\end{array}$ & $\begin{array}{l}6 \\
6\end{array}$ & o (n.s.) \\
\hline $\mathrm{N}$ & $\begin{array}{l}\text { right } \\
\text { left }\end{array}$ & $\begin{array}{l}7 \\
7\end{array}$ & $\begin{array}{l}\mathrm{O} \\
\mathrm{o}\end{array}$ (n.s.) \\
\hline
\end{tabular}


the other hand ectopic bone formation in Group L was found linear in the postero-medial site and below the greater trochanter (Fig. 4).
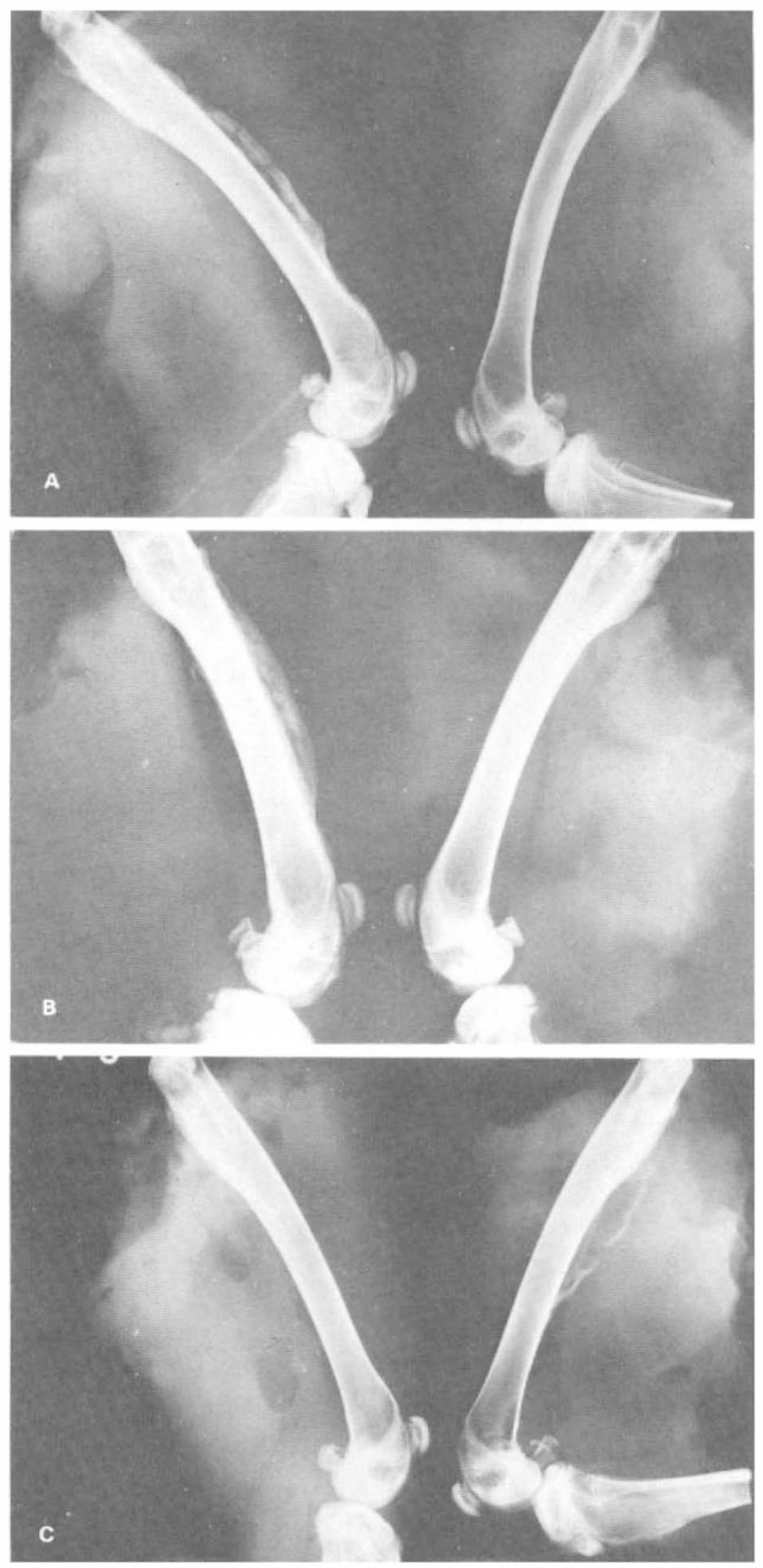

FIG. 4

Soft X-ray pictures in Group J (A), K (B) and L (C), zonal ossification in Group J and K, linear ossification in Group L are shown. 
Histologically in Group J subperiosteal haematoma was organized and many cartilage cells were seen and were calcified. Thus in Group J a so-called 'endochondral ossification' was mainly observed (Fig. 5). These preparations were made partially from the cross-sections of the right thighs removed femurs.
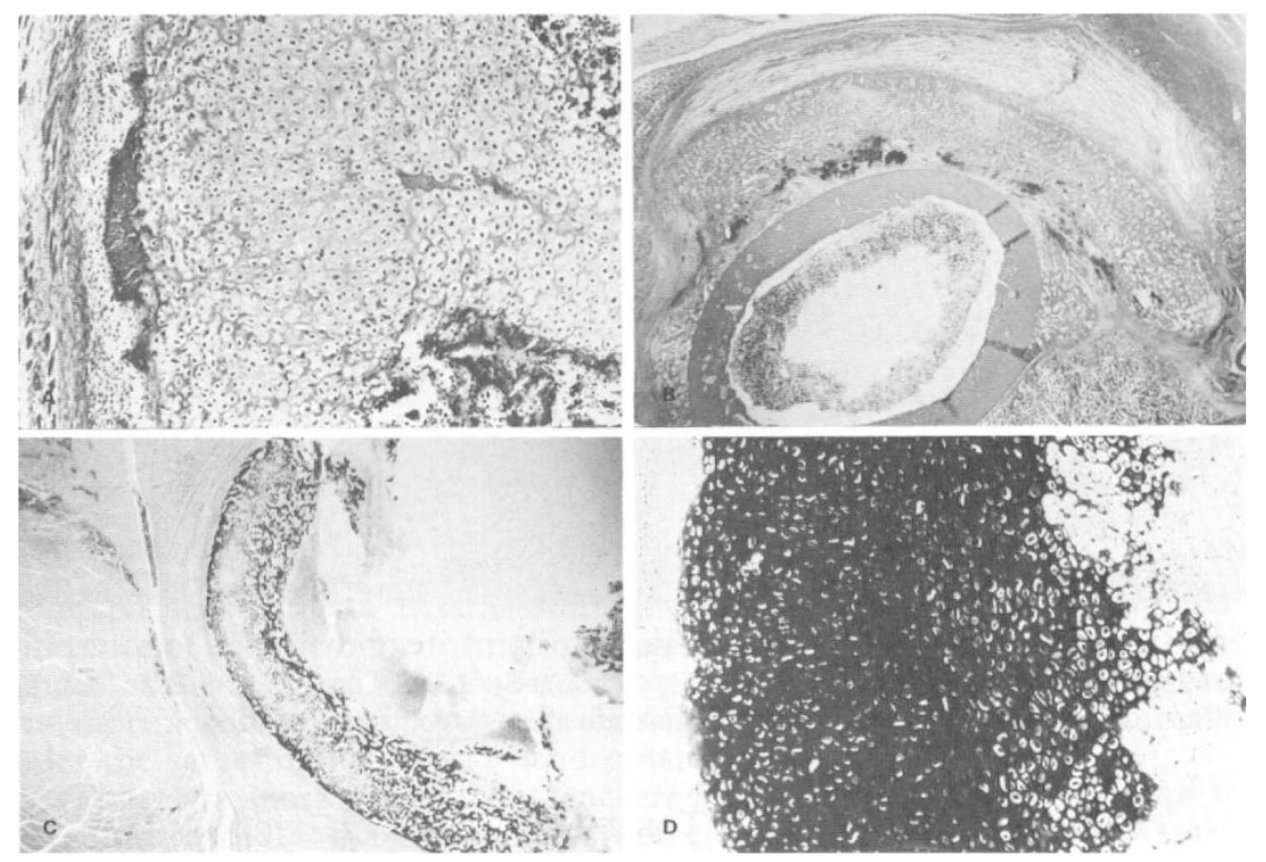

FIG. 5

Histological findings in Group J, A; H.E. $(\times 300)$, B; H.E. $(\times 60)$, C; V.K. $(\times 60)$, D; S.O.F. $(\times 300)$, enchondral ossification is observed.

The histological findings of ectopic bone formation in Group L were almost similar to those of ectopic bone formation in Group J (Fig. 7). On the other hand none or scanty cartilage cells appeared and woven bone margined by osteoblasts was observed mainly in Group $\mathrm{K}(\mathrm{P}<0.05$, Fisher's exact test) (Table IV, Fig. 6). Ectopic bone formation in three groups was localized between displaced periosteum and femur. Partial ossification extended into muscle through the ruptured periosteum (Fig. 8).

The blood gas of the right posterior leg measured just before sacrifice was compared between eight rabbits in Group J and seven rabbits in Group $\mathrm{K}$. Venous $\mathrm{PO}_{2}$ in Group $\mathrm{J}$ was significantly lower than venous $\mathrm{PO}_{2}$ in Group K $(P<0.05$, analysis of variance). There was no significant difference between the two groups regarding venous $\mathrm{PCO}_{2}, \mathrm{pH}$, arterial $\mathrm{PO}_{2}, \mathrm{PCO}_{2}$, and $\mathrm{pH}$ (Fig. 9).

\section{Discussion}

Urist discovered the bone and cartilage inductive capacity of $0.6 \mathrm{~N} \mathrm{HCL}$ 

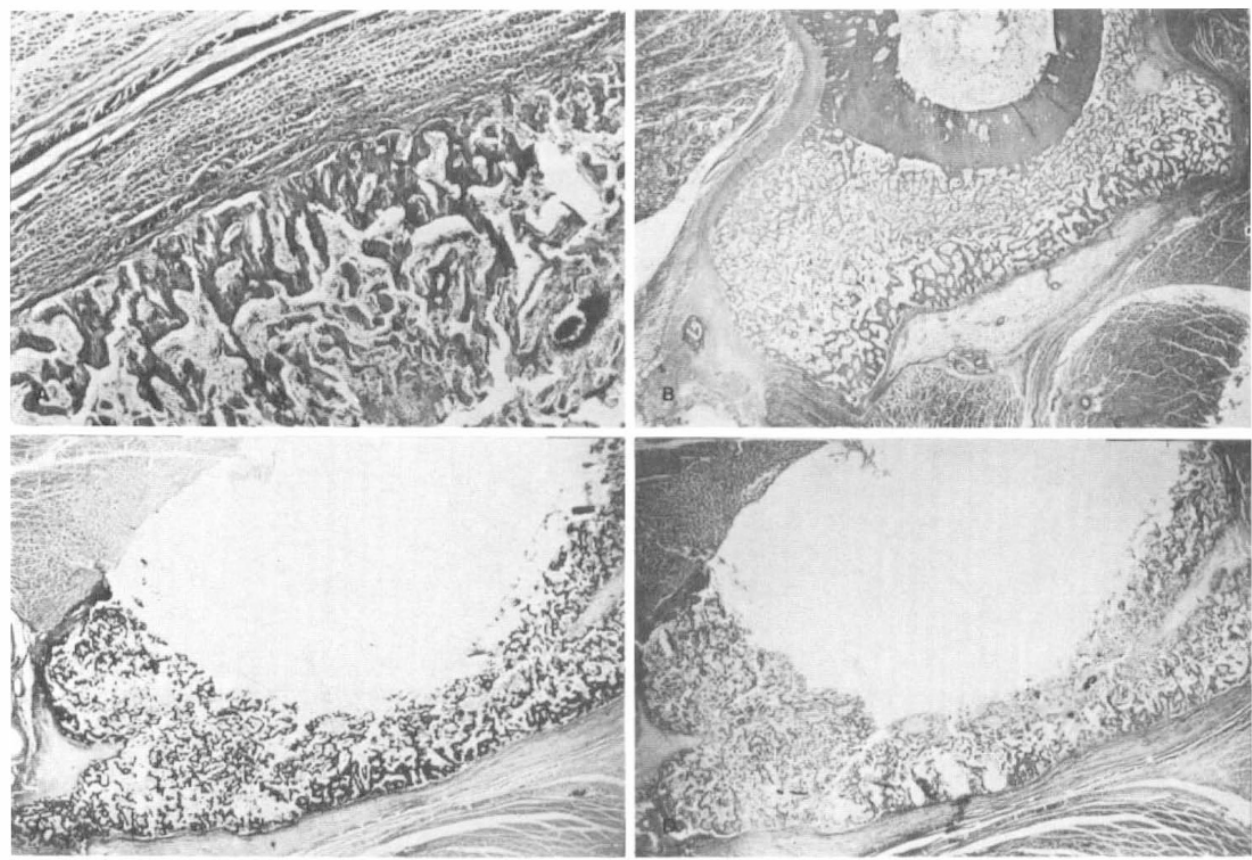

FIG. 6

Histological findings in Group K, A; H.E. $(\times 300)$, B; H.E. $(\times 60)$, C; S.O.F. $(\times 60)$, D; V.K. $(\times 60)$, woven bone margined by osteoblasts is seen.

TABLE IV

Histological findings of bone formed cases

\begin{tabular}{|c|c|c|c|}
\hline & & No. of rabbits & Enchondral ossification \\
\hline \multirow{2}{*}{$\mathrm{J}$} & right & 8 & 8 \\
\hline & left & 2 & 2 \\
\hline $\mathrm{K}$ & right & 9 & 4 \\
\hline L & left & 2 & I \\
\hline
\end{tabular}

$\mathrm{p}<0.05^{\star}$, Fisher's exact test; see text in detail.

decalcified bone matrix (DBM) in 1965 . We performed Experiment I to examine radiographically and histologically the influence of paraplegia upon ectopic bone formation which was induced with DBM. However contrary to our expectations there was no significant difference in the incidence of bone formation between paraplegic rabbits (Group A) and non-paraplegic rabbits (Group B). On the other hand on histological study, cartilage cells appeared more frequently in Group A than Group B at 3 weeks. We suspected that in paraplegia a so-called enchondral ossification was apt to occur for some reasons.

We then performed Experiment $I I$ to examine radiologically and histologically the influence of both paraplegia and of passive movements of the posterior legs, or of either upon ectopic bone formation which was 


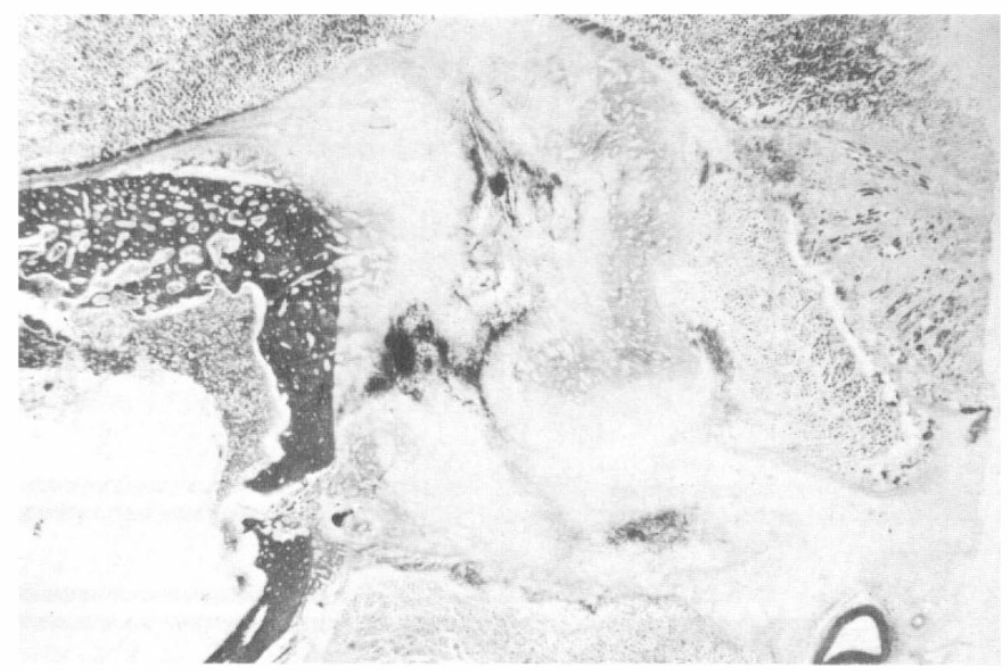

FIG. 7

Histological findings in Group L, H.E. ( $\times 60$ ), enchondral ossification is observed locally.

produced according to Michelsson's method. There was no significant difference of ectopic bone formation in soft X-ray pictures between Groups $\mathrm{J}$ and $\mathrm{K}$ as the result of Experiment $\mathrm{I}$. It was clear that ectopic bone formation is no more accelerated in paraplegia than in control (non-paraplegic animals) under the same immobilization and passive movement situation.

There are some reports that fractures in paraplegic patients are apt to heal more rapidly than in non-paraplegic patients (Eichenholtz, I963; Freehaffer et al., I98I). In these papers the authors reported that fractures in paraplegic patients healed rapidly with simple methods such as supporting the limb with pillows. However they did not compare the fracture healing period in paraplegics with that in non-paraplegics. We think that fractures of the paralysed legs in paraplegics heal easier using simple immobilization, as the affected legs are in a so-called immobilized condition because of the paralysis.

Ectopic bone occurred in the left legs of two rabbits in Group J. This was considered to be due to the affected legs being in an immobilized condition on account of the paralysis. However, it was unknown why ectopic bone did not occur in the left legs of the other eight rabbits in Group J. One rabbit with a decubitus ulcer the greater trochanter region in Group L had ectopic bone formation in the left leg. The animal had progressive flexion contracture of the knee and hip joints. Consequently it required a considerable forcible passive movement to maintain a normal range of motion. There are a few reports of the high correlation between decubitus pressure ulceration and heterotopic ossification (Damanski, I96r; Hassard, I975).

Histologically ectopic bone formation in Groups $\mathrm{J}, \mathrm{K}$ and $\mathrm{L}$ was localised between the displaced periosteum and femur. It was nothing more than ossification of a subperiosteal haematoma. Watson-Jones stated that the title 'myositis ossificans traumatica' was unfortunate because there 


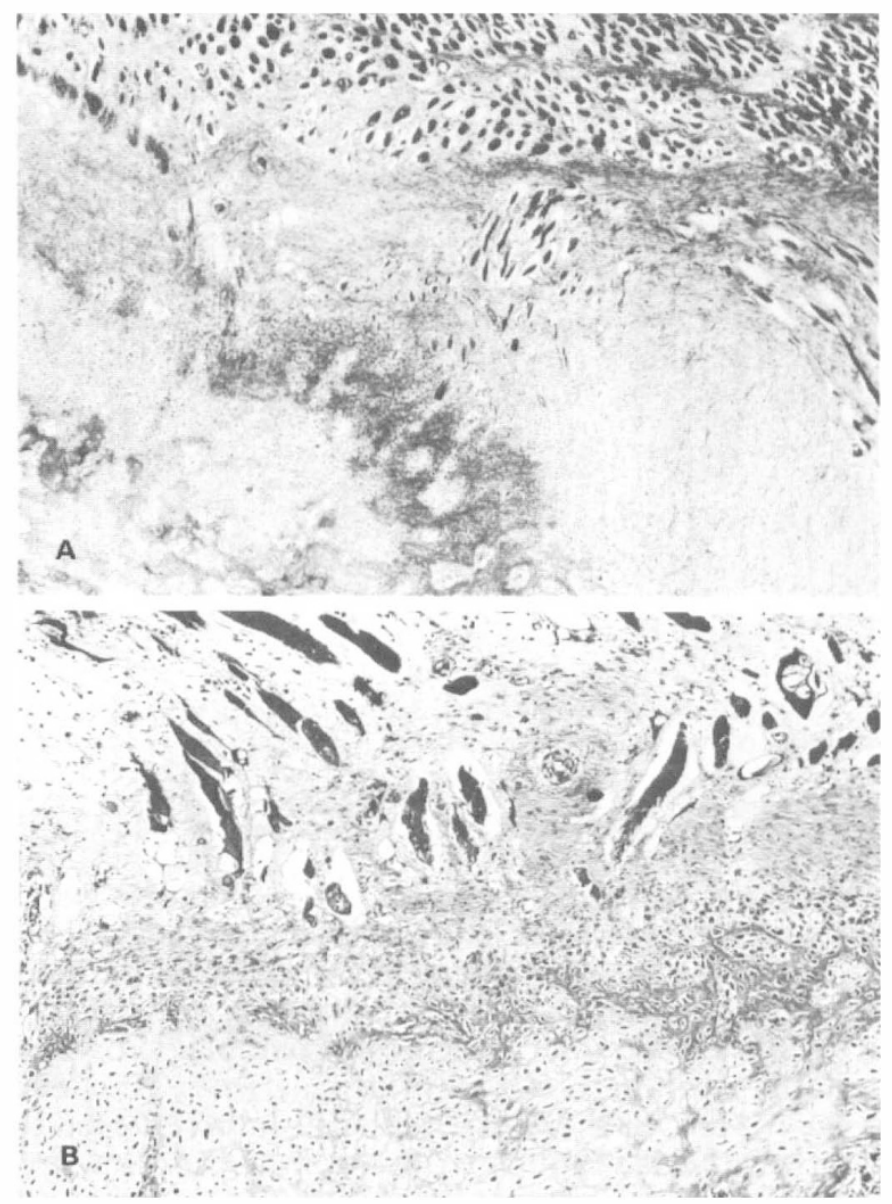

FIG. 8

Histological findings in Group J, A; H.E. ( $\times 60)$, B; H.E. ( $\times$ I 50), Ossification extends into muscle through ruptured periosteum, degenerated muscle is seen.

was no myositis and no ossification in the muscles, and the condition was quite different from the congenital abnormality 'myositis ossificans progressiva' in which bone was actually laid down in the muscle bellies (WatsonJones, 1962). We have also called the subperiosteal ossification ectopic bone formation.

Enchondral ossification was observed significantly more frequently in Group J than in Group K. Why was enchondral ossification observed more frequently at 3 weeks in Groups A and J with paraplegia? Bassett described that mesenchymal cells could differentiate into osteoblasts or chondroblasts or fibroblasts according to the environment, in particular in relation to oxygen tension (Bassett et al., I96I; Bassett, I962). He proved that under low oxygen tension and compaction mesenchymal cells differentiated into chondroblasts. Nogami \& Urist (1974) reported that decalcified bone matrix with a crevice more frequently induced chondrocyte 

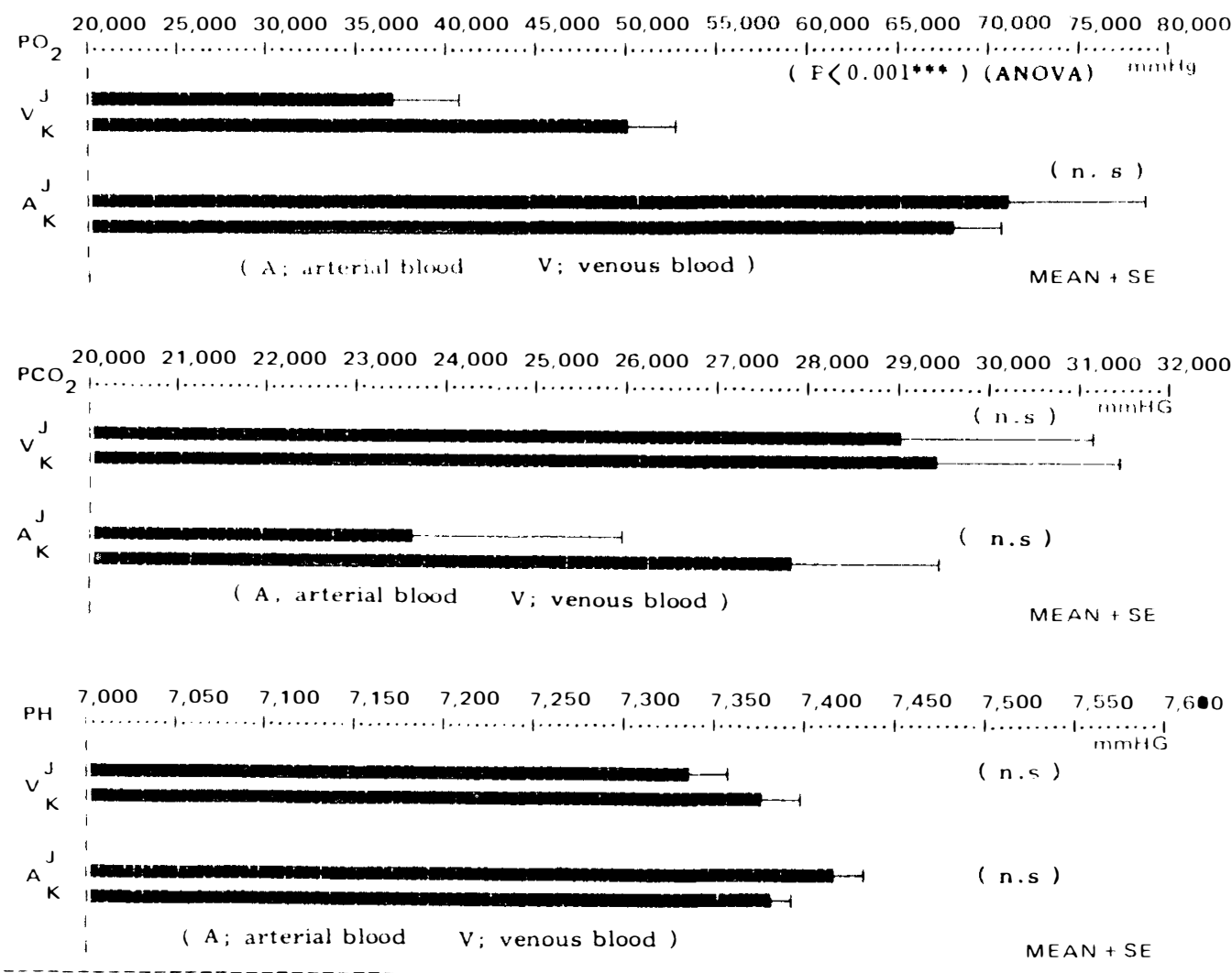

FIG. 9

Blood gas of the right posterior legs in Group $\mathrm{J}$ and $\mathrm{K}$, Venous $\mathrm{PO}_{2}$ in Group $\mathrm{J}$ were significantly lower than venous $\mathrm{PO}_{2}$ in Group $\mathrm{K}$.

formation, felt that anoxia in a closed area such as a crevice in the bone matrix was presumed to control the differentiation and proliferation of cartilage. Rossier reported that an absence of early venous return was found in early angiograms from the 5-40th day after injury, and observed this in the chronic stage of spinal cord trauma usually after $3-5$ th months. He stated that the early venous return was due to the opening of arteriovenous shunts (Rossier et al. I972). We speculated therefore that the paralytic legs have stasis of blood before arteriovenous shunts open. Lee found that femoral venous oxygen concentrations were lower than cubital venous oxygen concentrations in paraplegic patients for one month after injury (Van Slyk's method) (Lee, I962). Yonetani showed by an ultrasonic Doppler method that the contracture and deformity of joints and the muscle atrophy in the paralytic limbs of chronic spinal cord injured patients caused an increase of the peripheral resistance blood flow (Yonetani, I977).

We proved that femoral venous $\mathrm{PO}_{2}$ in Group J was significantly lower than femoral venous $\mathrm{PO}_{2}$ in Group $\mathrm{K}$, and that there was no significant difference between femoral arterial $\mathrm{PO}_{2}$ in Group $\mathrm{J}$ and femoral 
arterial $\mathrm{PO}_{2}$ in Group $\mathrm{K}$. This suggests that the paraplegic limbs in Group J might be subjected to blood stasis. We presume that cartilage cells appeared more frequently in Group J than in Group $\mathrm{K}$ and enchondral ossification was observed more frequently in Group A and Group J through Experiment I to Experiment II.

\section{RÉSUMÉ}

Aucune différence significative d'incidence de l'ossification ectopique n'a été observée entre un lapin paraplégique et celui non-paraplégique sous la même immobilisation et le même mouvement passif des jambes postérieures. Ce résultat nous suggère que lés ectopique puisse être produit par le mouvement passif forcé des extrémités paralytiques parcce que les extrémités dún patient paraplégique se trouvent immobilisées par leur paralysie. Histologiquement, lóssification enchondrale significative a été observêe plus fréquemment dans un lapin paraplégique que dans celui non-paraplégique, ce qui semble interprétable par la hypoxémie causée par la stase sanguine dans sés jambes paralytiques.

\section{ZUSAMMENFASSUNG}

Bei gleicher Immobilisierung und passiver Bewegung der Hinterbeine wurde kein bedeutsamer Unterschied im Auftreten von ektopischen Knochenformationen zwischen paraplegischen und nicht paraplegischen Kaninchen gefunden. Dieses Ergebnis deutet darauf hin, daß ektopische Knochen durch zwangsweise passive Bewegung der gelähmten Beine erzeugt werden können, da sich die Beine paraplegischer Patienten durch die Lähmung in immobilisiertem Zustand befinden.

Histologisch wurde enchondrale Verknöcherung bei paraplegischen Kaninchen bedeutend häufiger als bei nicht paraplegischen Kaninchen beobachtet. Wir vermuten, daß die Ursache hierfür in einem durch Blutstasis verursachten sauerstoffarmen Zustand der gelähmten Beine liegt.

\section{Acknowledgment}

We are deeply grateful to T. Kitagawa, M.D., Professor of Department of Orthopedic Surgery, Kumamoto University Medical School for his advice and support and wish to express our appreciation to Miss J. Nakajima for her assistance.

\section{REFERENCES}

Bassett, C. A. L. \& HerrmanN, I. (196I). Influence of oxygen concentration and mechanical factors on differentiation of connective tissue in vitro. Nature, 190, $460-46 \mathrm{I}$.

BASSETT, C. A. L. (1962). Current concepts of bone formation. F. Bone and foint Surg., $44 A$, I 2 I 7 - 1244.

CouvÉE, L. M. (I97I). Heterotopic ossification and the surgical treatment of serious contractures. Paraplegia, 9, 89-93.

DAMANSKI, M. (I96I). Heterotopic ossification in paraplegia. A clinical study. F. Bone and Foint Surg., 43B, 286-299.

Déjérine, M. M. E., Cellier, A. \& Déjérine, Y. V. (I9I9). Para-osteoarthropaties des paraplégiques par lésion médullaire. Etude anatomique et histologique. Rev. Neurol., 26, 399-407.

EICHENHOLTZ, S. N. (1963). Management of long-bone fractures in paraplegic patients. 7. Bone and foint Surg., 45A, 299-310.

Freehaffer, A. A., HAZEI, C. M. \& BeCKeR, C. L. (198I). Lower extermity fractures in patients with spinal cord injury. Paraplegia, 19, 367-372.

GutTMANN, Sir L. (1973). Spinal cord injuries, comprehensive management and research, Ist edn, pp. 207-217. Oxford: Blackwell Scientific Publications.

HASSARD, G. H. (1975). Heterotopic bone formation about the hip and unilateral decubitus ulcers in spinal cord injury. Arch. Phys. Med. Rehabil., 56, 355-358. 
Hernandez, A. M. (1978). The para-articular ossifications in our paraplegics and tetraplegics. Paraplegia, 16, 272-275.

LEE, W. K. (1962). Studies on heterotopic ossification in paraplegics. F. Fap. Orthop. Ass., 37, I-25.

Michelsson, J. E., Granroth, G. \& Andersson, L. C. (1980). Myositis ossificans following forcible manipulation of the leg. F. Bone and foint Surg., 62A, 8 I I-8I 5 .

Nogami, H. \& URIST, M. R. (1974). Explants, transplants and implants of a cartilage and bone morphogenetic matrix. Clin. orthop., I03, 235-25I.

Rossier, A. B., Bussat, Ph. \& Infante, F. et al. (I973). Current facts on para-osteoarthropathy (POA). Paraplegia, II, 36-78.

Rusk, H. A. (I964). Rehabilitation medicine, 2 nd edn, pp. 498-530. St Louis: C. V. Mosby.

SCHER, A. T. (1976). The incidence of ectopic bone formation in post-traumatic paraplegic patients of different racial group. Paraplegia, 14, 202-206.

Silver, J. R. (1969). Heterotopic ossification. A clinical study of its possible relationship to trauma. Paraplegia, 7, 220-230.

TAKADA, K. (1977). Clinical and experimental studies on ectopic ossification in the area of paralysis due to spinal injuries. Kotsutaisya, 10, 2 17-222.

UrIst, M. R. (1965). Bone formation by autoinduction. Science, I 50, 893-899.

WATSON-JONES, S. R. (1962). Fractures and foint Injuries, 4th edn, pp. 56-63. Edinburgh: Churchill Livingstone.

YoNETANI, T. (1977). Studies on the circulatory behaviour in patients with chronic spinal injury by ultrasonic Doppler method. f. fap. Orthop. Ass., 5I, 277-289. 